The University of Akron

\title{
IdeaExchange@UAkron
}

Proceedings from the Document Academy

University of Akron Press Managed

June 2016

\section{Sense in Documentary Reference: Documentation, Literature, and the Post-documentary Perspective}

Ronald E. Day

Indiana University - Bloomington, roday@indiana.edu

Please take a moment to share how this work helps you through this survey. Your feedback will be important as we plan further development of our repository.

Follow this and additional works at: https://ideaexchange.uakron.edu/docam

Part of the Scholarly Communication Commons, and the Scholarly Publishing Commons

\section{Recommended Citation}

Day, Ronald E. (2016) "Sense in Documentary Reference: Documentation, Literature, and the Post-documentary Perspective," Proceedings from the Document Academy: Vol. 3 : Iss. 1 , Article 6.

DOI: https://doi.org/10.35492/docam/3/1/6

Available at: https://ideaexchange.uakron.edu/docam/vol3/iss1/6

This Article is brought to you for free and open access by University of Akron Press Managed at IdeaExchange@UAkron, the institutional repository of The University of Akron in Akron, Ohio, USA. It has been accepted for inclusion in Proceedings from the Document Academy by an authorized administrator of

IdeaExchange@UAkron.For more information, please contact mjon@uakron.edu, uapress@uakron.edu. 


\section{Reference as Representation}

In modern documentation theory and practice, documents are often viewed as content holding forms. Indeed, in the information science tradition that Paul Otlet could be said to have originated, 'information' is understood as the meaningful content of documents. Information is said to be 'fixed' by documents as physical objects. As Balnaves and Willson (2011) argue, what they call the Otlet tradition of information differs from what they call the Cutter tradition because in the latter it is the material item (e.g., the paper document or the virtual document) that is called 'information' or 'document,' whereas in the Otlet tradition it is the ideational content of such that is seen as being the information or document.

For Otlet the content of documents (i.e., its information) are representations of the world. This means that all documents, as information bearing texts, are 'scientific' in the mode of a positivist or representational view of science. Moreover, Otlet in his Traité de documentation: le livre sur le livre: théorie et pratique (Otlet, 1934) has a hierarchy of documentary representations, starting from the representation of particular entities to the depiction of the essence of such entities. Following a metaphysical and epistemological tradition from Plato (with his notion of 'ideas' as the true content of individual entities) and Aristotle (for whom philosophy, too, sought the essences or 'truth' of entities) up until the modern period, for Otlet the highest scientific truths are found in the most abstract, or 'abstracted' documents, drawn from other, more descriptive documents. Documentation is seen as becoming more scientific in its collection of scientific texts when it reduces them to their essence or 'aboutness,' just as scientific texts are viewed as having reduced individual entities (e.g., individual frogs) to their essence or truth (e.g., universal frog behavior or any other aspect of their 'frogness').

Both the representational aspect and the hierarchical reductionistic aspect of Otlet's documentation theory and practice can be seen in the following two illustrations, respectively, from Otlet's 1934 book, Traité de documentation: le livre sur le livre: théorie et pratique (Otlet, 1934). It should be remembered that far from exemplifying a forgotten moment, Otlet's epistemological commitments sometimes continue today in documentation and information science theory and practice in the activities of indexing, information metrics, and information visualization, among many other research and professional activities. 

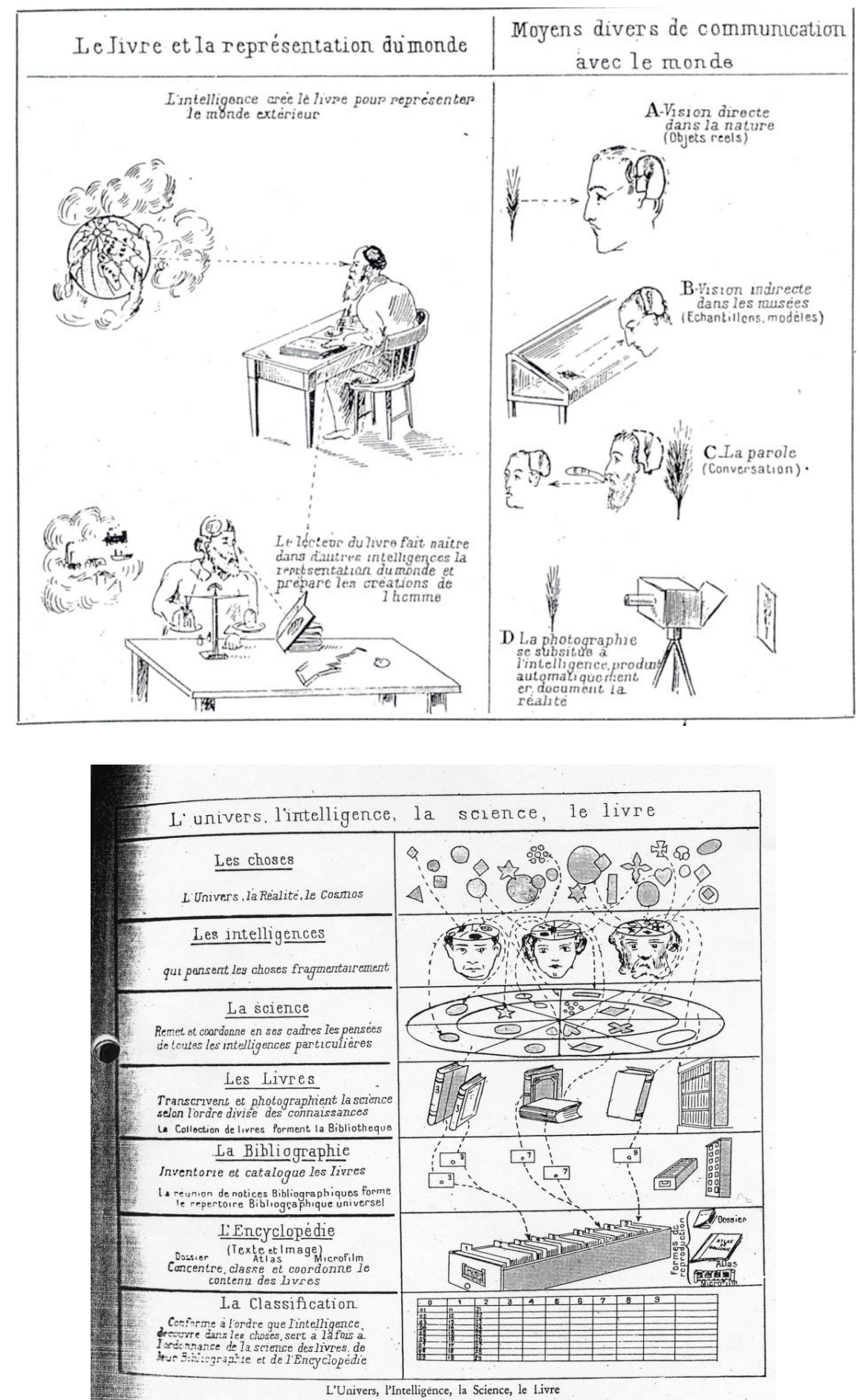

Illustrations from Otlet (1934) 
In the first illustration we see knowledge depicted as representations of the world in the mind and in various documentary materials, such as books, and most iconically, photographs. In the second, we see how the work of science and documentation (at its highest level and most 'scientific' manner for Otlet) is understood not as naïve empirical representation or experimental representation (Frohmann, 2004; Shapin, 1984), but rather as representative assertions of truth about the world. In a return to Aristotelian and medieval science, facts don't belong to empirical events, but rather to documentary signs and theory, though in a highly reductionist documentary form-namely documentary abstracts, classification taxonomies, and ultimately bibliographic codes (such as classification numbers). At the highest levels of knowledge and truth, documents, for Otlet, do not represent beings, things, and events, but the essences of such. Such essences and their relationships are shown in ontologies, taxonomies, and classification schemes.

\section{Documents as Pictures}

For Paul Otlet, documents contain assertions - statements - of truth about the world. The collection of such statements/documents constitute what Otlet called (after the theological concept of the book of God) "Le Livre" ("the Book"), which like Otlet's notion of a world library, or, literally, Otlet's Mundaneum, constitutes the total picture of the world via collections of statement/documents.

In the language of contemporary philosophy, Otlet's epistemology is called a 'picture theory' of knowledge. A picture theory epistemology holds that truth resides in the correspondence of statements to states of the world. What separates picture theories like Otlet's — or most famously that of the philosopher Ludwig Wittgenstein in his 1921 Tractatus Logico-Philosophicus-from the naïve empiricism of John Locke and others British philosophers and experimentalists (Shapin, 1984) of the $17^{\text {th }}$ and $18^{\text {th }}$ centuries, is that the former is not empiricism at all, but a type of representationalism or 'positivism' which aims to depict essential and universal truths about entities in the statements of science, rather than seeing such statements (theory) as being provisional and possible (or likely) explanations about the results of experiments upon particular entities. That is, picture theories follow a correspondence theory of truth, understanding truth as the correspondence of descriptive (i.e., statements) or literal pictures about the world and the essential reality of entities - in terms of medieval philosophy, adaequatio rei et intellectus. Theoria in Ancient Greek means to look at things from a distance; in the philosophical tradition and in modern positivism, it is precisely this distance that is understood as necessary for seeing the entity in its truth, a truth that may be hidden by the phenomenological changes of individual beings and entities. 
Indeed, Otlet's epistemology of documents as representational statements of facts and his understanding of universal bibliography as the representation of the world in its totality so closely resemble Wittgenstein's 'logical positivist' epistemology in the latter's Tractatus Logico-Philosophicus that one could easily substitute "document" for "fact" in the second and third propositions that begin Wittgenstein's (1921) work, as I do below:

1. The world is all that is the case.

1.1. The world [of knowledge, i.e., collections of statementsbooks, the documentary collection/library/catalog; "Le Livre"] is the totality of facts [statements/documents], not of things.

1.11. The world [of knowledge, i.e., collections of statementsbooks, the documentary collection/library/catalog; "Le Livre"] is determined by the facts [statements/documents], and by their being all the facts [statements/documents]).

Otlet's Traité not only repeats the epistemological assumptions of logical positivism expressed in works such as Wittgenstein' Tractatus, but his Traité also uses some of the same formal, rhetorical devices as Wittgenstein did in his Tractatus, namely 'atomic' rhetorical units (akin to Otlet's "monographic principle" of atomic documents), rhetorical units that are built up into more complex rhetorical units (such as paragraphs, book sections, chapters, etc.). In this way, and through the use of simple sentences (representing simple statements) and "monographic" paragraphs and book sections built into larger wholes, the text performs the analytic-synthetic science that it asserts as the true form of knowledge. This can be seen not only in the rhetorical form of the Traité's text, but also in the documentary organization of the text as a whole, according to an analytical-synthetic numerical system. For example, compare the numerical rhetorical form of Wittgenstein's Tractatus (as quoted above and modified for content) to the table of contents in Otlet's Traité:
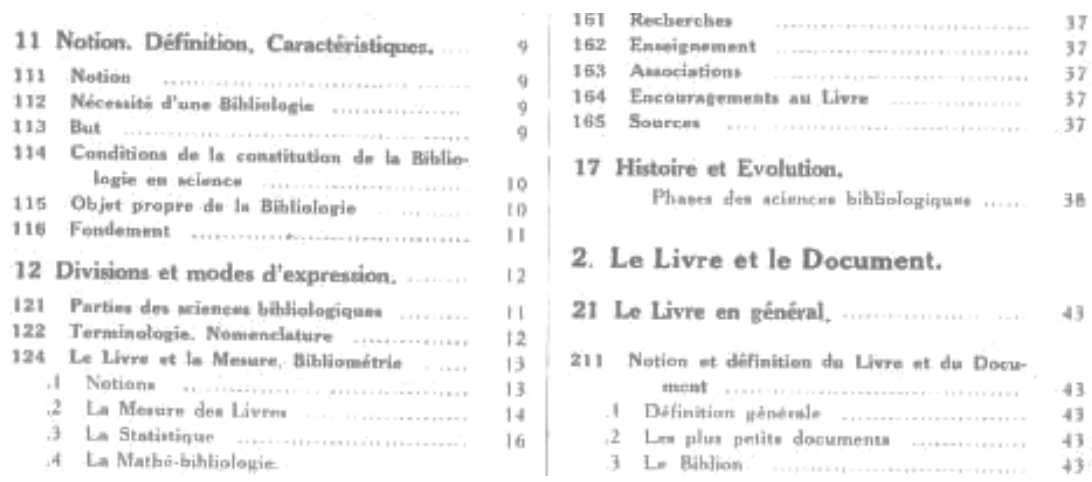

Numerical organization in the table of contents of Otlet (1934) 


\section{Sense in Reference}

If the Otlet tradition (Balnaves and Willson, 2011) of documentation and information sees knowledge and truth as an issue of picturing the 'aboutness' of things (in other words, picturing their essential information or 'content'), then what is peculiar is that such an epistemology directs that one must abstract away from particular entities in order to get such universal or essential pictures.

To put it succinctly, the performance of truth in a representational notion of theory or documentation cannot find any equivalent in natural entities, per se, just as bibliographic abstracts and other forms of metadata representation must represent a text in another (at least much more reductive) form than that text. Frogs cannot be represented as to their essence except by abstracting away from particular frogs; they must be represented at a distance by their evidential or documentary essence. And so, consequently, we need to see that this documentary version of scientific representation is itself an essentialist, universal, and 'typological' epistemological and rhetorical performance, grounded in ontologies and taxonomies of types of entities rather than individual entities per se.

In the Western metaphysical tradition, reaching from Platonic and Aristotelian philosophy to modern positivist notions of knowledge and truth (that is to write, the entirety of Western philosophy understood as metaphysics), one must leave entities and go to statements of their essence in order for their essential truths or 'truth' to occur. One must depart from entities as particular in themselves, and rather believe that they contain essential elements of 'aboutness' that pertain to not only their own being, but that of others of their 'type,' and one must believe that this is where true knowledge or 'truth' lies. Not coincidently, this is also the method of representation in modern documentation via indexes, abstracts, titles, etc. - what used to be called 'metalanguage' and is now more frequently called 'metadata.' 'Aboutness' in modern documentation is the epistemology of the Western metaphysical tradition of representing essentialist evidence, in both theory and practice.

Documentation as 'information' is Western metaphysics, and Western metaphysics, from the very beginnings of Western philosophy and 'thought' until now proceeds through the material practices of documentation and the theory of documentation as a monological, evidentiary, practice and theory of knowledge and truth.

For this reason, studies into the politics and sociology of Western expansion throughout the world should take into account both Western metaphysics and both the theory and the practices of documentation in supporting such expansion. Equally, there can be no complete account of the appearance of 'Europe' in the modern period or 'the West' without accounts of the expansion 
and management of the colonies and more indirect 'Western influence' through documentary metaphysics and material documentary practices (Mignolo, 2003).

Indeed, the technology that we associate with the modern tradition of documentation (as well as with philosophy itself since Plato and Aristotle)'writing' - is well suited to Otlet's epistemology of representation, because it asserts not through dialogue, but through writing as a form of statement and broadcast. Writing itself is the activity of reading what someone else has written; even dialogues, such as Plato's dialogues, perform 'monologically,' not dialogically through 'writing.' 'Writing,' as we have known it as 'documents' is monologic communication toward, in the modern sense of the term, 'information.' By their very nature, monologic inscriptions lend themselves to an epistemology of statements or assertions, to giving information about something - to being signs or indicators of what is not readily apparent without theory (at the very least in terms of naming or nomenclature and in terms of systems of identity and differences).

What happens to the modern documentation - or, more generally, the modern documentary - paradigm if modern documentary tools, such as index cards, are no longer the means by which something becomes meaningful as knowledge?

We can begin to answer such a question by way of a contrast: in acts of conversation things, actions, and events are more or less agreed upon ('understood') based on each participant in a conversation trading with the others their senses of what to think or act upon a thing, being, or event in a situation. Here, 'aboutness' is not based on documentary naming and representation, but on dialogue and pragmatic, and often temporary, agreements to proceed with the conversation or to act on it. Clarity and distinctness of reference in conversations may be incomplete at any one moment, but this does not stop actions from coming from such, and, in fact, the continuance of interactions among the participants is what they hope will lead to better understanding and actions.

In communication, unlike documentary information, reference is less determined by representation, and it is more determined by multiple senses. As documentary systems approach the radical temporality and dialogical qualities of communicative functions then they take on more communicative notions of 'information,' and this has radical effects upon how we understand both documents and a modern notion of information that has come from the documentary tradition of the past twenty-five hundred years, but particularly during modernity.

Buckland (2015) has suggested that with modern documentation systems we often lose the "context" or sense that gives referential meaning to terms. This is because 'aboutness' is representationally determined through bibliographic nomenclature, classification, and domain specificity, for example, but with a very 
diminished linguistic grammar and an even more impoverished, what we'll call, 'social grammar.' So, for example, in ordinary language the word "fire" in itself is hardly sufficient to account for different types of fires and their effects. (For example, to know if I should run out of the house or if I should approach the fireplace, I need to understand the term not only in a broader linguistic grammar, but also, in a social situation.) And to understand whether and with what I should fight an out of control fire, it would helpful to have someone to converse with, so that I can then better measure the threat and so that I can better work with this other person in order to contain or extinguish the fire.

At minimum, linguistic meaning requires three types of sense affordances for expression: 1) a cultural form (the form of a word-e.g., in English, "fire"), 2) a socially normative use (how the word is deployed in a given social situatione.g., "fire!"), and 3) a physical or physically imagined situation (the physical situation and entities to which the term refers, alone or in combination with other words - e.g., "there is a fire in the house"). These cultural, social, and physical sense affordances give to an expression its referent. From this, we derive the notion of a representation or an 'idea.' Representations are consequences of these three affordances for expressing and making sense.

Modern documentation systems make up for their lack of the second and third affordances, by the use of 'controlled' systematic identities and differences and syndetic references (e.g., "'dog,' not 'cat'"; no 'catdog' in LCSH; for "'canine' see 'dog'"), by subdivisions (geographic and temporal), and by thesauri structures of broader, narrower, and synonymous terms, among other techniques. Even then, however, reference fails if there's still ambiguity in language or if users lack knowledge of the indexing structure being used.

In brief, modern documentation systems lack many of the elements of ordinary language that help work out ambiguities and create possibilities for understanding and action to occur. In contrast with ordinary language, controlled vocabulary and classification 'languages' are strange and very reduced, and so their abilities to express and reference are poor. We would never expect anyone to communicate in ordinary language with something like Library of Congress Subject Headings, but because of the materials and metaphysics within which modern documentation systems evolved, we have relied on such things to organize and access knowledge.

In regard to limited domains of language use, largely of a representational kind, documentary systems of pre-coordinate indexing and classification can work well enough to represent or at least index documents made up of limited discursive grammars (e.g., 'frog' in scientific texts likely refers to a type of amphibian and is not likely to be used as a derogatory term for French people, and so constitutes an adequate descriptive term for locating scientific documents and information on such amphibians). But in more heterogeneous domains of 
language, the representational means of traditional indexing and classification miserably fail in creating reference. Representational 'naming' fails in providing the complex grammars or 'sense' needed for making, understanding, and acting upon expressions in most of our daily and even professional interactions; that is, for creating meaningful references. For this reason, modern documentary techniques need to be repurposed or improved upon in order to come closer to the power and flexibility of ordinary language. We will return to this topic shortly in a brief discussion of post-documentary technologies.

\section{'Literature'}

In order to better understand the limits of reference through representation in modern documentation, it is helpful to look at a counter-tradition to such. The emergence of the category of "literature" in the $18^{\text {th }}$ century as a genre for fictional works and poetry is an excellent case.

In Otlet's works, the ultimate epistemic form for a document is that it be evidence of a "fact." It does this through representations, which themselves are claimed to be facts, and as we have seen are the basis for the claimed facticity of the essential being and relations of the world. The facticity of entities in the world relies upon documents of their essential nature; such essential natures paradoxically give to entities their facticity. In Otlet's work, ultimately it is the documentary evidence of the fact that becomes the fact, and the facticity of the entity depends upon this.

Literary works pose an issue for such a notion of reference for several reasons. First, literary works can be said to be about many different things, and so for this reason a work in literature is not bibliographically described by the 'aboutness' of its content, but rather as evidence of an author's oeuvre or literary genre or historical period - that is, it is described by form and function. Second, in regard to the realist tradition of literature, though the goal of such works is representation, this is done at the level of imagined empirical description, rather than that of the description of the essences of entities. In realism, it is the immediacy and particularities of individuals as individuals that are depicted, even when they represent social or psychological types (as in Émile Zola's novels, for example). Third, an abstract or summary of a novel or poem is not seriously claimed to be the meaningful equivalent of such; the rhetorical performance is so integral to the meaning of the original work that an abstraction of its 'aboutness' is seen as constituting a different work altogether. We cannot know the character of Emma Bovary very well without reading Flaubert's Madame Bovary. The representation of Emma Bovary is known through the complex sensual presentation that the work uses to express the character. And last, particularly in the modern avant-garde tradition of literature and especially in poetics, the 
meaning of the work lies in its performance or being read, which lends to it a radical temporality of meaning; the 'ideas' in a Shakespearean play depend on reading or live performance for an audience of a given time and place.

For these reasons, the Western tradition sees such works as works of 'rhetoric' or sophistry or artistry, and not of philosophy (and in modernity, science). And literary texts and literature in the modern period find an uncomfortable fit in the genre of documents and information, even though such texts have physical documentary form and they give, in some meaning of the term, 'information' to the reader or audience. In Otlet's Traité there is an awkward ambiguity to the meaning of 'littérature, ' meaning both inscriptions generally and literature as a genre of aesthetic or artistic works.

The category of literature (as a genre of aesthetic or artistic works) contests: 1) documentary representations of essences and hierarchies of abstraction without losses of meaning (as we saw in the two, earlier, Otlet illustrations), 2) the 'fixed' or permanent nature of representation claimed by documentary descriptions as descriptions of the essential information or 'aboutness' of texts and entities or cases in the world, and 3) universalist claims toward the representation of knowledge in a text or in the world. Instead, literary works in modernity refer through empirical particulars, and their claims of truth are either based on performance and self-reflexivity (as in the avant-garde) or analogical modeling and a reader's application-'imagination' (the realist tradition).

The category of literature as having these genre characteristics is unique to the notion of fictional and poetic works in the modern period. Earlier literary works had these qualities, of course, but the notion of 'literature' as something more sensual, both more descriptively realistic and more self-reflexively material and aware of its construction than scientific documentation, is a modern phenomenon. Possibly its development was a reaction to the essentialist and universalist claims of science as a science of documentary representation, as well as being an aesthetic extension of empirical realism in early modern science without the latter's use of technology and method.

In literature, sense is stressed as a means of reference. Even with when representations are used, they are used in a mode of descriptive empirical completeness and artifactual awareness. Representation is inflected through the performance or presentation. Imagined and real situational affordances play an important role in giving meaning to cultural forms. In realist fiction, on the one hand, complex social affordances combine to give meaning to terms and to present imagined situations that work as models for the reader. And on the other hand, with the artistic modern avant-garde, social norms are contested by technique, resulting in the defamiliarization and 'making bare of the devices' of 
the social, cultural, and material technologies operating in both the literary and artistic works and the documentary modes of representation that they critique.

\section{Post-documentary Technologies}

Recent computational information and communication technologies, which I call "post-documentary," may incorporate documentation techniques of information retrieval, but toward more communicative ends.

Technologies such as social network algorithms, GPS enabled locators, and recursive computing algorithms increase the cultural, social, and physical attributes of indexed terms and thus can vastly increase the precision and flexibility of reference for both human and machine users and agents, particularly in real-time interactions. Consequently, the notion of 'documents' can move closer to communicative functions.

Post-documentary technologies produce multiple ruptures within the modernist opposition of (scientific) documentation and literature. In regard to modern documentation, post-documentary technologies introduce time-valued and site-specific indexing and retrieval. They shift the meaning of 'information' from a documentation to a communication perspective, from a monologic to a dialogic determination of reference. Historically, they mark a substantial shift from the monologic tradition of documentation, suggesting to some that we now live in an increasingly oral cultural environment, paradoxically led by the booming use of computer mediated communication and document retrieval.

Post-documentary technologies challenge both the a priori nature of knowledge as documentation and the meaning of 'literature' as an oppositional term to 'documents' and 'information,' in the modernist sense of these terms. It is claimed that post-documentary technologies are concerned with indexing and representing particulars, performatively in real time, and with a greater descriptive completeness (in the case of social big data, for example) as compared to traditional documents. By producing time-valued and site-specific narratives with particular agents in a broad range of knowledge, emotions, and social interactions, post-documentary technologies encroach upon the very meaning of 'literature' in modernity. Two differences that remain are, first, that of 'showing the devices' of their own constructions (which are notoriously opaque in the case of online algorithms and indexing), and second, that narrative fiction still largely appears as representation rather than as lived presentation (and so remains in opposition within the same register-representation — as that of modern documentation). 


\section{Conclusion}

What remains clear in regard to documents and information today is that 'sense' is making sense again in regard to information. Today's post-documentary technologies cross what were distinct information, communication, and media ecologies.

In ways both technological and (perhaps still lagging) socio-culturally, the modern age of documentation is past. But in other ways, perhaps, it continues on, but is now sometimes sublimated to higher levels of infrastructural embeddedness or abstraction (Day, 2014; Thomas, 2013).

Reference, meaning, and sense in the post-documentary age still needs to be thought, but this task is more momentous than that of a mere disciplinary considerations in information science or documentation. Asking 'what is a document?' today is asking 'how can one think and be?', against the backdrop of the modern documentary tradition and Western metaphysics.

\section{References}

Buckland, M. K. (2015). Classification, links and contexts. Classification \& Authority Control: Expanding Resources Discovery. Proceedings of the International UDC Seminar, 29-30 October 2015, Lisbon Portugal, ed. by Aida Slavic \& Maria Inês Cordeiro. Würzburg: Ergon Verlag. 1-16. Available at people.ischool.berkeley.edu/ buckland/lisbon15.pdf

Day, R. E. (2014). Indexing it All: The Subject in the Age of Documentation, Information, and Data. Cambridge, Mass.: MIT Press.

Frohmann, B. (2004). Deflating Information: From Science Studies to Documentation. Toronto: University of Toronto Press.

Mignolo, W. (2003). The darker side of the Renaissance : literacy, territoriality, and colonization (2nd ed. ed.). Ann Arbor :: University of Michigan Press.

Otlet, P. (1934). Traité de documentation: le livre sur le livre: théorie et pratique. Brussels: Editiones Mundaneum, Palais Mondial.

Shapin, S. (1984). Pump and circumstance: Robert Boyle's literary technology. Social Studies of Science, 14, 481-520.

Thomas, N. (2013). Social Computing and the Manufacture of Sense. Paper presented at the Americas Conference on Information Systems $\underline{\text { http://aisel.aisnet.org/cgi/viewcontent.cgi? } \text { article }=1514 \& \text { context=amcis20 }}$ $\underline{13}$ 